v. 8, n.4

Vitória-ES, Oct. - Dec. 2011.

p. $67-88 \quad$ ISSN 1808-2386 DOI:http://dx.doi.org/10.15728/bbr.2011.8.4.4

\title{
Analysis of the use of a four-factor model as a tool to help manage portfolios based on the IBrX
}

\author{
Luiz Eduardo Carvalho Terra de Faria ${ }^{\dagger}$ \\ Pontifícia Universidade Católica do Rio de Janeiro (PUC-RIO) \\ Walter Lee Ness Jr. ${ }^{\Omega}$ \\ Pontifícia Universidade Católica do Rio de Janeiro (PUC-RIO) \\ Marcelo Cabus Klotzle ${ }^{¥}$ \\ Pontifícia Universidade Católica do Rio de Janeiro (PUC-RIO) \\ Antonio Carlos Figueiredo Pinto ${ }^{\mathfrak{f}}$ \\ Pontifícia Universidade Católica do Rio de Janeiro (PUC-RIO)
}

\begin{abstract}
Using the price series of the assets that compose the $\mathrm{IBrX}$ in the period from May 2002 to December 2007, this article examines the influence of the variables beta, market value, price-earnings ratio and book-to-market ratio on the behavior of the Brazilian stock market, comparing the results with those of other studies carried out in Brazil. On investigating the influence of beta, we sought to verify if the premises of the CAPM are valid in the model proposed. We used the SUR and TSCS techniques to estimate the influence of the variables. The results indicate the significance of price-earnings and market value, but the book-to-market ratio presented the greatest stability and was significant in all the proposed models. In relation to the CAPM, the study shows that all the variables analyzed had some degree of influence on the cross-sectional variations of the average stock returns, indicating that other factors besides beta can be associated with the behavior of the assets.
\end{abstract}

Key words: CAPM; IBrX; price-earnings ratio; market value; book-to-market ratio.

Received on 09/07/2009; reviewed on 06/23/2010; accepted on 08/05/2010; available in 10/21/2011

Corresponding authors *:

\begin{tabular}{|c|c|c|}
\hline \multirow{4}{*}{$\begin{array}{r}\text { business } \\
\text { Pontifical }\end{array}$} & ${ }^{\Omega} \mathrm{Ph} . \mathrm{D}$. in economics from the & Ph.D. in economics from \\
\hline & Massachusetts Institute of & Katholische Universität Eichstätt \\
\hline & Technology (EUA). & (Germany). \\
\hline & Institution: Pontifical Catholic & Institution: Pontifical Catholic \\
\hline $\begin{array}{l}\text { stitution: Pontifical Catholic } \\
\text { iiversity of Rio de Janeiro }\end{array}$ & $\begin{array}{l}\text { University of Rio de Janeiro } \\
\text { (PUC-RIO). }\end{array}$ & $\begin{array}{l}\text { University of Rio de Janeiro } \\
\text { (PUC-RIO). }\end{array}$ \\
\hline UC-RIO). & Address: Rua Marquês de São & Address: Rua Marquês de São \\
\hline $\begin{array}{l}\text { Idress: Rua Marquês de São } \\
\text { cente 225 Gávea - Rio de }\end{array}$ & Vicente, 225, Gávea - Rio de & $\begin{array}{l}\text { Vicente, 225, Gávea - Rio de } \\
\text { Janeiro-RJ-Brazil }\end{array}$ \\
\hline leiro - RJ - Brazil. & $\begin{array}{l}\text { Janeiro - RJ - Brazil } \\
\text { CEP: } 22453-900\end{array}$ & $\begin{array}{l}\text { Janeiro - RJ - Braz } \\
\text { CEP: } 22453-900\end{array}$ \\
\hline : 22453-900 & E-mail: ness@iag.puc-rio.br & Email: klotzle@iag.puc-rio.br \\
\hline $\begin{array}{l}\text {-mail:_ado_rj@ yahoo.com.bi } \\
\text { elephone: (21) } 21389201\end{array}$ & Telephone: (21) 2138-9201 & reiepnone. $(21) 2150$ \\
\hline
\end{tabular}

${ }^{£} \mathrm{Ph} . \mathrm{D}$. in economics from Getulio Vargas Foundation (FGV/RIO) Institution: Pontifical Catholic University of Rio de Janeiro (PUC-RIO).

Address: Rua Marquês de São Vicente, 225, Gávea - Rio de Janeiro - RJ - Brazil CEP: $22453-900$

E-mail: figueiredo@iag.puc-rio.br Telephone: (21) 2138-9201

Telephone: (21) 2138920

Note from the Editor: This article was accepted by Antonio Lopo Martinez. 


\section{INTRODUCTION}

The Brazilian economy has undergone great transformations with the stabilization process that started with the Real Plan in July 1994. Among these changes are the country's investment fund industry, which has become more sophisticated, with increased specialization and rivalry of its participants.

According to the National Association of Investment Banks (Associação Nacional de Bancos de Investimento - ANBID), in December 2007, the industry reached R\$ 1 trillion in assets managed. This expansion has motivated fund managers and other professionals in this segment to study new asset management tools with the aim of aggregating more value to their clients, especially for those investing in the variable income market.

The study of portfolio composition to try to maximize the returns from investments in stocks is not new. It was basically developed starting in the 1950 s with the seminal work of Markowitz (1952), who formulated a model with a quantitative approach to measure risk, for the purpose of optimizing portfolios. This work, along with that of other authors, led to the development of the capital asset pricing model (CAPM).

Based on studies testing the CAPM, new works were developed challenging the use of beta as a simple measure of an asset's risk. Among these were studies using financial variables related to companies or the market as a whole and their variability. These variables can be employed to capture information on the risks associated with each firm. Many of these studies revealed incompatibilities in the movement of prices with the concepts established by the traditional pricing models, defined as anomalies in the financial literature. Among these, we can mention those of Chan, Hamao \& Lakonishok (1991), Fama \& French (1992 and 1993) and Carhart (1997).

In Brazil, studies of the theme have been conducted by Hazzan (1991), Braga, Costa Jr. \& Mescolin (1997), Lima Jr. (2003), Malaga \& Securato, 2004 and Medeiros (2009), among others.

The main objective of this study thus consists of investigating the influence of the factors beta, price-earnings ratio $(\mathrm{P} / \mathrm{E})$, market value, or firm size, and book-to-market ratio $(\mathrm{B} / \mathrm{M})$ on the returns of the shares of Brazilian companies that compose the theoretical portfolio of the IBrX, in the period from May 2002 to December 2007. We use this asset price series to identify which of the above variables has greater influence on the cross-sectional variations of the average stock returns. 
By identifying the relative influence of these variables and comparing the results with the findings of other international and national studies, this work contributes to the study of the financial anomalies in the Brazilian capital market. Therefore, portfolio managers can benefit from the evidence on these anomalies to try to generate better returns on their portfolios.

\section{THEORETICAL FRAMEWORK}

\subsection{INTERNATIONAL STUDIES}

A series of studies have shown the existence of regularities in the behavior of asset prices that can be characterized as inconsistent (or anomalous) with respect both to the hypothesis of market efficiency and the traditional asset pricing models. These works document that it is possible to explain the difference found between the average returns of assets when controlling for differences in the systematic risk existing between them, which is measured by the beta coefficient of the CAPM, using variables such as market capitalization (Banz, 1981), the price-earnings ratio (Basu, 1977) or the book-to-market ratio (Chan, Hamao \& Lakonishok, 1991; Fama \& French, 1992).

Basu (1977) sought to demonstrate the relationship between the performance of stocks and their P/E ratio in the American market, analyzing companies listed on the NYSE between 1956 and 1971. Initially he stratified different portfolios according to the P/E factor and concluded that those with the lowest $\mathrm{P} / \mathrm{E}$ ratio presented higher risk-adjusted return than portfolios with higher P/E ratios. Finally, he demonstrated the superiority of an annual rebalancing strategy, according to the lowest $\mathrm{P} / \mathrm{E}$ criterion, to permit investors to obtain abnormal returns in relation to portfolios chosen at random with the same systematic risk (given by beta, or $\beta$ ).

Banz (1981), in turn, also using data for the American stock market, found a higher riskadjusted return for firms with lower market capitalization in comparison with those with higher market value. This finding became known as the "size effect". He found evidence of problems if misspecification of the CAPM, where he verified that on average small cap firms on the NYSE presented higher risk-adjusted returns than large companies during the period considered. He further found that this size effect was not linear in relation to the market proportion (or its logarithm), but was higher in the small companies in the sample.

In the past two decades, the work of Fama \& French (1992) particularly stands out in this respect. They analyzed all the shares of non-financial firms traded on the three main 
American exchanges during the period from 1963 to 1990. They surprised the market by failing to find a significant relation between return and systematic risk and that other value indicators, such as the book-to-market ratio and dividend earnings, were more closely associated with the returns of the stocks analyzed. The main results presented, in summary, were: a) value stocks provide higher average annual returns than do growth stocks and those with lower beta; and b) when the effects of beta are separated from the size effects, the relationship between beta and the average returns is flat. In this sense, the authors suggested that the book-to-market ratio and size were the factors that best explain the return of the stocks analyzed.

Chan, Hamao \& Lakonishok (1991) carried out a study of Japanese stocks between January 1971 and December 1988, seeking to relate the differences between the returns with four fundamental variables: earnings yield, size (market value), book-to-market ratio and cash flow yield. Of the four variables investigated, the authors concluded that the book-to-market ratio and cash flow yield had the most significant impact on expected returns.

Carhart (1997) performed a study that added the momentum effect to the three traditional factors of the model of Fama \& French (1992), so that his model became known as the "four-factor model". The momentum effect had been noted a few years before by Jegadeesh \& Titman (1993), who discovered that stocks with low returns in the three and twelve preceding months tended to perform worse in the three and twelve following months, while stocks with extraordinary returns in the same periods exhibited a tendency to maintain high returns in the next three and twelve months. Carhart (1997) operationalized the momentum effect as being the beta associated with the difference in the return between winning and losing portfolios, which were formed and corrected monthly. The study by Carhart (1997) was based on monthly data for mutual funds from 1963 to 1992 and found empirical evidence demonstrating the superiority of his four-factor mode over the three-factor one of Fama \& French (1992) in explaining stock returns.

The above studies were revolutionary in the sense of including new variables that could better explain stock returns in relation to a model with a single factor, the CAPM. Thus, the studies of Basu (1977) and Banz (1981) showed, respectively, the importance of the P/E ratio and size. The effect of these two variables was confirmed when Fama \& French (1992) introduced their famous three-factor model, showing that when the book-to-market ratio and size were introduced into the model, the market beta lost significance. The model of Fama \& French (1992) was then incremented by that of Carhart (1997) when he introduced the 
momentum effect in addition to their three factors and demonstrated that this factor considerably increased the explanation of stock returns. Finally, the study of Chan, Hamao \& Lakonishok (1991) was innovative in the sense of suggesting the inclusion of other variables of an accounting nature, such as earnings yield and cash flow yield, in models to explain stock returns.

\subsection{STUDIES OF THE BRAZILIAN MARKET}

Hazzan (1991) tested the P/E ratio for the period between June 1981 and May 1988 with the aim of analyzing the anomalies of the P/E and size effect, on portfolios of shares traded on the São Paulo Stock Exchange (Bovespa). The results indicated that portfolios composed of stocks with lower $\mathrm{P} / \mathrm{E}$ ratios outperformed those with higher $\mathrm{P} / \mathrm{E}$ ratios.

Neves (1996) examined the influence of the variables beta, market value, P/E ratio and $\mathrm{B} / \mathrm{M}$ ratio, utilizing shares traded on the Bovespa during the period from March 1987 and February 1996. He found an influence of the variables analyzed, with the most significant being beta, followed by B/M.

Braga, Costa Jr. \& Mescolin (1997), employing the methodology presented by Fama \& French (1995), analyzed the risk-return relation between value and growth stocks utilizing portfolios formed by B/M, earnings per share (EPS) and dividend yield (DIV), for the period from January 1986 to June 1996. The authors found the occurrence of an additional absolute return for value portfolios without this being explained by the occurrence of higher risk, characterized by beta. They also failed to find a similar effect for the variables earnings/price and dividend yield.

Rodrigues (2000) applied the three-factor model of Fama \& French and found an effect of market value in the Brazilian market for the period from June 1991 to May 1999. He concluded for the existence of an inverse size effect, whereby firms with higher capitalization obtained higher returns during the study period. He also found a very high correlation coefficient (0.62) between the variables HML (high minus low) and SMB (small minus big), using regression models in his analysis in which the effects of value and size were never present simultaneously.

Malaga \& Securato (2004) also tested the three-factor model of Fama \& French for shares listed on the Bovespa, in the period from 1995 to 2003. The objective of the study was to identify if variations in the stock returns could be explained by three factors: beta, firm size and book-to-market ratio $(\mathrm{B} / \mathrm{M})$. The results indicated that not only was the three-factor 
model superior to the CAPM in explaining the returns in the sample utilized, all three factors were statistically significant. However, the premium for size was negative, indicating that in the Brazilian market, larger firms offer better returns than smaller ones.

Lima Jr. (2003) conducted a study of stock price anomalies in the Brazilian market for the period from June 1994 to December 2001 utilizing the model of Carhart (1997). The fundamental variables utilized were momentum, market capitalization, market-to-book ratio (the inverse of $\mathrm{B} / \mathrm{M}$ ) and momentum (calculated as the return in the immediately preceding quarter). The author found the occurrence of the size effect in the Brazilian market, that is, a higher risk-adjusted return for firms with higher $\mathrm{B} / \mathrm{M}$ ratios. However, the momentum factor was not significant, showing the superiority of the three-factor model of Fama \& French.

Mussa, Santos \& Famá (2007) also tested the four-factor model in the Brazilian market, but reached opposite results to those of Lima Jr. (2003). Their sample consisted of shares traded on the Bovespa in the period from 1995 to 2006 and the four-factor model was superior to the three-factor one of Fama \& French and to the CAPM. Of the four factors, beta was the most consistent, explaining part of the variations in all the portfolios and models tested. The other three additional factors (size, B/M ratio and momentum) were also significant, but the relevance of each factor varied according to the characteristics of each portfolio formed. Another interesting point was that unlike in the study of Fama \& French (1992), the premium for the size factor was negative, corroborating the finding of Málaga \& Securato (2004). The premium for the momentum factor was also negative, in contrast to the finding of Carhart (1997) for the American market.

Neto (2008) compared the model of Carhart (1997) with the three-factor model of Fama \& French for the Brazilian market in the period from January 1997 to December 2006. A first interesting result was that the inclusion of the momentum effect did not increase the model's explanatory power in relation to the three-factor model, which in turn was superior to the CAPM. The factor that was most significant was size, since the portfolios with smaller firms outperformed those formed of larger companies.

Medeiros (2009) analyzed the stock returns of Brazilian electricity companies between 1997 and 2007 using the CAPM, the model of Fama \& French (1992) and that of Carhart (1997). The factor with the strongest explanatory power was beta, evidencing the superiority of the CAPM over those of Fama \& French and Carhart. 
An analysis of the studies of the Brazilian market reveals there is no clear superiority of one factor or of one model over another, and also that some results partially depart from international studies. These differences refer to the existence of the size effect, but in the reverse sense, where larger companies perform better than smaller ones (Mussa, Santos \& Famá, 2007; Malaga \& Securato, 2004 and Rodrigues, 2000), as well as the non-significance of the momentum factor (Lima Jr., 2003; Neto, 2008 and Medeiros, 2009) and the negative relation between momentum and performance (Mussa, Santos \& Famá, 2007).

\section{METHODOLOGY}

The present study uses regressions with panel data. This technique permits combining time series and cross-sectional data, increasing the amount of information available.

According to Hsiao (1986), another advantage of the method is to increase the degrees of freedom, consequently diminishing the colinearity between the explanatory variables, because it permits using a larger number of observations.

The general model for panel data is represented by:

$$
y_{i t}=\beta_{o i t}+\beta_{1 i t} x_{1 i t}+\ldots+\beta_{n i t} x_{k i t}+e_{i t}
$$

In this notation, the subscript $\mathrm{i}$ denotes the different individuals and $\mathrm{t}$ indicates the time period, while $\beta_{\text {oit }}$ corresponds to the intercept parameter and $\beta_{n i t}$ is the angular coefficient corresponding to the $\mathrm{k}$-th explanatory variable of the model.

Among the models that combine time series and cross-sectional data, three are most commonly used: the first is the SUR (seemingly unrelated regression), which is used in this study, while the other two are the fixed effects and the random effects models, not used in this study.

In relation to the general panel data model, the SUR has some particular specifications, as shown below, according to Hill, Griffiths \& Judge (1999):

$$
\beta_{o i t}=\beta_{o i} \quad \beta_{1 i t}=\beta_{1 i} \ldots \beta_{k i t}=\beta_{k i}
$$

With these alterations, the SUR model assumes that the intercept and the response parameters differ among the individuals but remain constant over time. Therefore, the model is given by:

$$
y_{i t}=\beta_{o i}+\beta_{1 i} x_{1 i t}+\ldots+\beta_{k i} x_{k i t}+e_{i t}
$$

Besides this, there are two basic suppositions of the SUR model: 


$$
\begin{gathered}
\operatorname{Var}\left(e_{i t}\right)=\sigma^{2}{ }_{i} \quad e \operatorname{Var}\left(e_{j t}\right)=\sigma^{2}{ }_{j}, \text { with } \sigma^{2}{ }_{i} \neq \sigma^{2}{ }_{j} \\
\operatorname{Cov}\left(\mathrm{e}_{i t}, \mathrm{e}_{j t}\right)=\sigma_{i j} \neq 0
\end{gathered}
$$

The first assumption indicates that the variance of the error term is constant, but alternates from one equation to another, signaling the occurrence of heteroskedasticity among the different units observed. The second assumption is the existence of contemporaneous correlation. In other words, it indicates there is a correlation between the errors of the different equations for the same time period. Due to this, the SUR model utilizes, in a second stage, the generalized least squares (GLS) method, considering the contemporaneous correlation between the residuals and providing a better unbiased estimator.

The study is based on all shares traded on the Bovespa belonging to the theoretical portfolio of the IBrX (Brazil index), in the period from May 2002 to December 2007. We could have updated the series until December 2009, to include the period of the subprime crisis, but this would have caused a problem by introducing a structural break in the series, at the moment the impact was felt in the Brazilian capital market. It is important to stress that in using time series models, the question of stability of the parameters over the sample interval must always be considered. The existence of at least one structural change can result in errors of inference and prediction if those breaks are not duly taken into account (Brooks, 2008).

To assess whether there was any structural break in the period under analysis, in this study we used the evolution of the IBrX-50, since the market capitalization of this index is very near that of the index of the overall Bovespa, the Ibovespa (BMFBovespa, 2010). Figure 1 shows the evolution of the IBrX-50 from May 2002 to December 2009. As can be observed, there is an abrupt break in May 2008, with recovery only starting in February 2009.

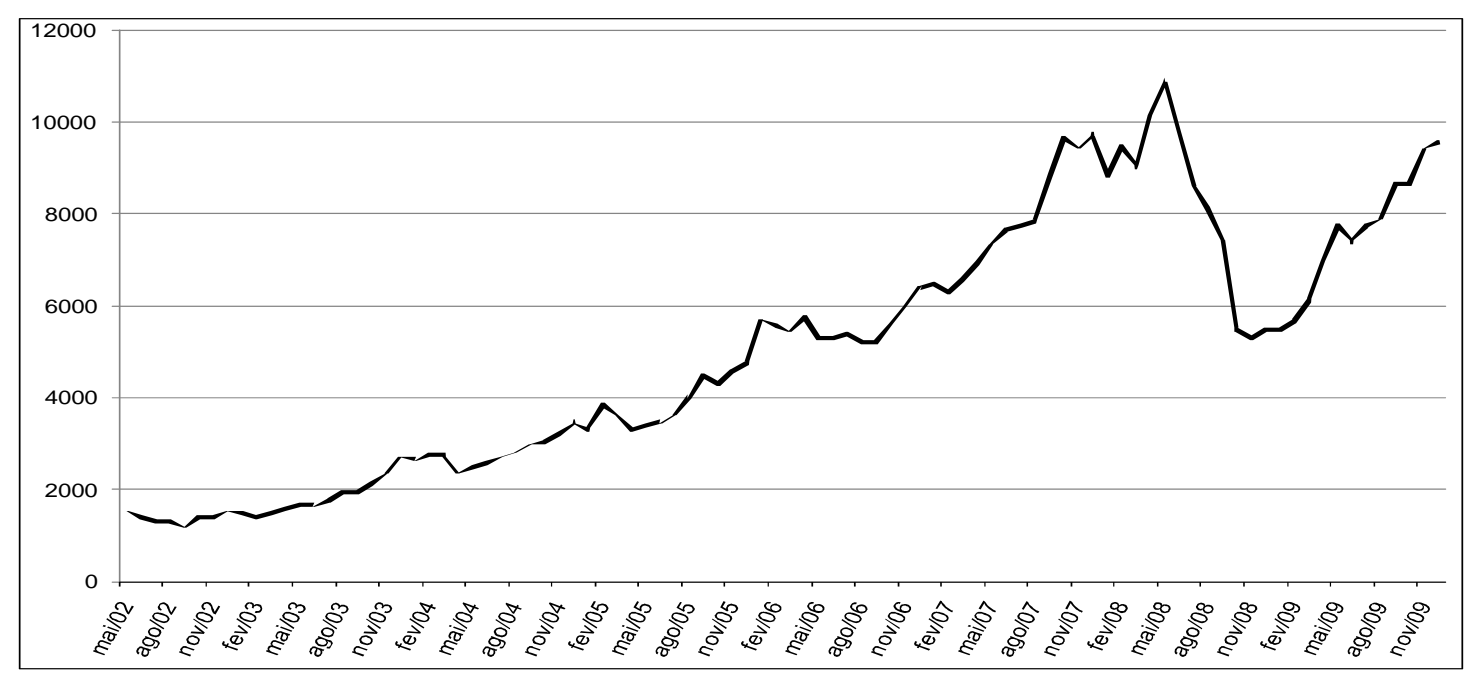

Figure 1: Evolution of the IBrX-50 in the period from May 2002 to December 2009

Source: Calculated by the authors based on data from the BMFBovespa 
Based on this, we applied the Chow stability test to examine whether there was a structural break in May 2008.

The Chow test permits testing the structural stability of the model estimated or verifying structural changes over the estimation period. It is based on the following hypotheses:

$H_{0}$ : the coefficients in two different periods are equal

$H_{A}$ : the coefficients are different

The Chow test involves the following steps (Brooks, 2008):

1) Divide the total period $T$ into two sub-periods with $T_{1}$ and $T_{2}$ observations, respectively.

2) Estimate the model with all the observations $T=T_{1}+T_{2}$ and determine the sum of the squares of the residuals $\left(\mathrm{SQR}_{\mathrm{T}}\right)$, with $\mathrm{T}_{1}+\mathrm{T}_{2}-\mathrm{k}$ degrees of freedom, where $\mathrm{k}$ is the total number of coefficients in the model.

3) Estimate the model separately in periods $T_{1}$ and $T_{2}$ and determine the sum of the squares of the residuals for both $\left(\mathrm{SQR}_{1}\right.$ and $\left.\mathrm{SQR} \mathrm{R}_{2}\right)$, with $\mathrm{T}_{1-\mathrm{k}}$ and $\mathrm{T}_{2-\mathrm{k}}$ degrees of freedom, respectively.

4) Define the F-statistic as follows:

$$
F=\frac{\left[S Q R_{T}-\left(S Q R_{1}+S Q R_{2}\right\rangle\right] / k}{\left(S Q R_{-}+S Q R_{2}\right) /\left(T_{1}+T_{2}-2 k\right)} \sim F_{k, T+T-2 k}
$$

The criterion of stability or equality of the coefficients in the two periods (hypothesis $\mathrm{H}_{0}$ ) implies that:

$$
F<F_{T_{1}+T_{2}-2 k}(1-\alpha)
$$

Table 1 shows the result of the Chow test for May 2008 for the division of the total period:

Table 1: Chow stability test for the log of the IBrX 50 for the month of May 2008 Period: May 2002 to December 2009

F-statistic 27.58695 P-value of the F-statistic F(1.91)
0.0000

As can be seen in Table 1, the null hypothesis of the absence of a structural break in May 2008 was rejected at a significance level of 1\%, implying that in Many 2008 there was an abrupt shift in the series' trend. Based on this, we limited the study period only up to December 2007. 
For the risk-free rate of return, which is necessary for the CAPM, we used the SELIC rate, which is the benchmark rate, set by the Brazilian Central Bank.

Initially we constructed portfolios balanced by the P/E ratio (price-earning ratio) and market value with constant shares in the theoretical portfolios of the $\mathrm{IBrX}$ for the period indicated above. The theoretical portfolio of this index has a lifetime of four months, running from January to April, May to August and September to December. Therefore, we rebalanced the portfolios under analysis every four months.

To assure that the formation of the stock portfolios was based on accounting information from the year before and widely known by the public, we estimated the fundamental variables based on the balance sheets referring to December $31^{\text {st }}$ of the previous year.

Besides this, since we relied on balance sheet figures, it was necessary for all the companies selected to have presented their financial statements using the same accounting principles and that these referred to the fiscal year ended on December 31 st.

The fundamental variables employed were the following:

- Price-earnings ratio (P/E) - determined by dividing the closing price of the stock in month $t$ by the earnings per share in December of the previous year;

- Market value (MV) - determined by multiplying the closing price of the stock in month $t$ by the number of shares at the end of that same month;

- Book-to-market ratio $(\mathrm{B} / \mathrm{M})$ - determined by dividing the accounting value per share in December the previous year by the market value per share at the end of month $\mathrm{t}$.

Therefore, according to the above procedure, it can be stated that the monthly earnings per share represents the quotient between the net earnings ascertained in December of the preceding year and the number of shares calculated in each month of the current year, starting in May 2002, so that all the fundamental variables fluctuate within the proposed study period.

The calculation of the monthly nominal returns adjusted by earnings of the various shares, in turn, was based on the following equation:

$$
\mathrm{R}_{j, t}=\ln \left(\mathrm{P}_{j, t} / \mathrm{P}_{j, t-1}\right)
$$

Where:

$\mathrm{R}_{j, t}$ is the total return of stock $\mathrm{j}$ in month $\mathrm{t}$, in logarithmic form; 
$\mathrm{P}_{j, t}$ is the closing price of stock $\mathrm{j}$ in month $\mathrm{t}$, adjusted by all earnings in the period; $\mathrm{P}_{j, t-1}$ is the closing price of stock $\mathrm{j}$ in month $\mathrm{t}-1$.

In the process of forming the portfolios, we used the same procedure followed by Chan, Hamao \& Lakonishok (1991) and then adopted by Neves (1996), namely, ordered according to the three fundamental variables. For this, it was necessary to identify the minimum number of firms per portfolio in the Brazilian market. In this respect, the study of Brito (1989) deserves mention, which concluded that a portfolio composed of eight different firms eliminates most of the diversifiable risks in the Brazilian stock market.

In the first step of building the portfolios, the stocks that make up the portfolio of the $\mathrm{IBrX}$ were ordered in increasing form according to the $\mathrm{P} / \mathrm{E}$ variable. The initial aim of this procedure was to identify the stocks with negative results in the period. Then we divided the stocks into three groups. The first group (group 0) contained the stocks that had negative return, and hence negative $\mathrm{P} / \mathrm{E}$, which we did not analyze in this study. Groups 1 and 2 contained equal numbers of stocks, with positive and increasing P/E.

In the second step, we initially ordered the stocks by the P/E ratio and divided them into groups 1 and 2, then ordered them again, this time by the market value variable, and divided them into two new groups.

In the last step, we ordered the four groups by the book-to-market variable and divided each into two new groups, for a total of eight portfolios, containing an average of ten stocks in each one, all of which were included in the study.

After this portfolio formation process, we performed two additional processes to validate the results found by analyzing the eight initial portfolios.

The first consisted of inverting the ordering process of the portfolios, in two different ways. In the first, the stocks belonging to groups 1 and 2 (with positive P/E ratio) were initially ordered by the market value variable and then by the P/E variable, and finally by the $\mathrm{B} / \mathrm{M}$ variable, repeating the steps of the initial process, forming eight new portfolios. In the second, the stocks belonging to groups 1 and 2 were ordered by the $\mathrm{B} / \mathrm{M}$ variable, then by $\mathrm{P} / \mathrm{E}$ and finally by the market value variable, repeating all the steps in the first two processes, generating eight more portfolios.

The second method of constructing the portfolios consisted of repeating the ordering schemes for creation of the portfolios presented initially, but with the introduction of 
smoothing of the $\mathrm{P} / \mathrm{E}, \mathrm{MV}$ and $\mathrm{B} / \mathrm{M}$ variables through month-by-month division of the average cross section corresponding to the previous four months, accompanying the changes in the theoretical portfolio of the IBrX. Our aim here was to obtain greater stationarity of these variables. With this procedure, the database for the new portfolios constructed covered the period from September 2002 to December 2007, reducing the period analyzed from 68 to 64 months.

The econometric tests applied initially utilized the SUR (seemingly unrelated regression) method, also known as the joint generalized least squares regression or regression of Zellner (1962).

Following the research line employed by Chan, Hamao \& Lakonishok (1991) and later by Neves (1996), we also conducted a test by an alternative method to the SUR technique, consisting of a new verification of the results by times series cross-section (TSCS) analysis. This technique takes into consideration the autocorrelation and heteroskedasticity between the cross-sectional units over the time horizon. The model was the same as that for application of the SUR method.

The basic model of this study is based on the following equation:

$$
R_{p t}-R_{f t}=\alpha_{o}+\beta_{p 1}\left(R_{m}-R_{f}\right)+\alpha_{1}(P / E)_{p t}+\alpha_{2}(L M V)_{p t}+\alpha_{3}(B / M)_{p t}+\varepsilon_{p t}
$$

Where:

p represents the portfolios, varying from 1 to 8 ;

$t$ represents each monthly observation, varying from 1 to 68 ;

$\mathrm{R}_{p t}$ is the return of portfolio $\mathrm{p}$ in month $\mathrm{t}$;

$\mathrm{R}_{f t}$ is the risk-free interest rate in month $\mathrm{t}$;

$\mathrm{R}_{m}$ is the market return, represented by the IBrX;

$(\mathrm{P} / \mathrm{E})_{p t}$ é a média do $\mathrm{P} / \mathrm{E}$ das ações da carteira $\mathrm{p}$ no mês t;

$(\mathrm{LMV})_{p t}$ is the mean of the natural logarithm of the market value of the firms in the portfolio in month $\mathrm{t}$; and

$(\mathrm{B} / \mathrm{M})_{p t}$ is the mean quotient of the book value and market value of the stocks in the portfolio in month $\mathrm{t}$.

We estimated the beta $(\beta)$ by simple linear regression between the monthly returns of the stocks with the return of the IBrX. For this purpose, we used monthly returns for 24 months even though the study covers a period of 64 months. The reason was the limitations imposed by the composition of the IBrX, whose composition criterion establishes that the stocks must be among the 100 best classified regarding liquidity index in the 12 months prior 
to rebalancing and must have been traded in at least $70 \%$ of the trading sessions in the 12 preceding months to the portfolio formation.

\section{ANALYSIS OF THE RESULTS}

Table 2 contains a descriptive analysis of the portfolios formed by the three variables analyzed in this study, adopting the following procedure:

All the stocks belonging to the IBrX's theoretical portfolio, disclosed every four months, were ordered individually by the variables $\mathrm{P} / \mathrm{E}, \mathrm{MV}$ and $\mathrm{B} / \mathrm{M}$. Then four portfolios were formed for each of these variables, along with a special portfolio for variables with negative values (exclusively for the $\mathrm{P} / \mathrm{E}$ variable, since stocks with negative returns were not incorporated in the other portfolios because the premises of the study exclude these assets).

The table also presents the beta coefficients estimated by simple regression of each asset individually in relation to the $\mathrm{IBrX}$ and then weighted equally in the composition of each portfolio. The numbers in the market value field are in billions of reais $(\mathrm{R} \$)$.

The portfolios with a higher $\mathrm{P} / \mathrm{E}$ ratio presented a lower average return in the portfolios with positive P/E. In this respect, portfolios 1 and 2 stood out as having the highest absolute average return in the segment of portfolios ordered by P/E, of $2.65 \%$ per month for portfolio 1 and $3.04 \%$ for portfolio 2 . It should be noted that we chose to use the median instead of the mean of the P/E ratio, due to the existence of outliers in the database analyzed, which could have impaired the analysis of the information obtained.

The portfolios of firms with lower market value performed slightly better than those made up of firms with higher market cap, with portfolio 2 obtaining the best absolute monthly return, at 2.6\%. These results are consistent with those presented by Neto (2008) for the Brazilian market.

In relation to the returns presented by the $\mathrm{B} / \mathrm{M}$ ordering criterion, unlike observed in the studies described previously, the portfolio with the highest $\mathrm{B} / \mathrm{M}$ ratio, portfolio 4 , presented the lowest absolute return, of $1.9 \%$ a month.

The betas might be indicating a misspecification of the CAPM, since the portfolio that had the highest beta (1.12) had the lowest absolute return among all the portfolios analyzed, with an average return of $0.85 \%$ per month. Besides this, the portfolio with the second lowest beta (0.77) showed the highest average return for the period, of $3.04 \%$ per month. We should 
clarify that the returns were not risk adjusted and the betas of the portfolios changed every four months because of the method of composing the IBrX portfolio.

Table 2 - Descriptive statistics of the portfolios ordered by the fundamental variables

\begin{tabular}{lrrrrr}
\hline \multicolumn{7}{c}{ Panel A - Portfolios ordered by the P/E ratio } \\
\hline & Portfolio 0 & Portfolio 1 & Portfolio 2 & Portfolio 3 & Portfolio 4 \\
\hline P/E & $-37,2$ & 5,15 & 8,21 & 13,85 & 30,5 \\
MV & 56,49 & 14,87 & 12,25 & 16,28 & 11,49 \\
B/M & 1,49 & 1,36 & 0,9 & 0,89 & 0,84 \\
Return (\% per month) & 0,85 & 2,65 & 3,04 & 2,15 & 1,9 \\
Standard Deviation & 4,71 & 2,63 & 3,13 & 2,68 & 3,11 \\
$(\%)$ & 13 & 20 & 19 & 20 & 19 \\
N & 1,12 & 0,88 & 0,77 & 0,88 & 0,88 \\
$\beta$ IBrX & & & & & \\
\hline
\end{tabular}

\begin{tabular}{|c|c|c|c|c|c|}
\hline \multicolumn{6}{|c|}{ Panel B - Portfolios ordered by the market value } \\
\hline & Portfolio 0 & Portfolio 1 & Portfolio 2 & Portfolio 3 & Portfolio 4 \\
\hline $\mathrm{P} / \mathrm{E}$ & & 12.58 & 17.51 & 20.44 & 15.77 \\
\hline MV & & 22.39 & 49.26 & 97.62 & 44.49 \\
\hline $\mathrm{B} / \mathrm{M}$ & & 1.38 & 0.85 & 0.75 & 0.99 \\
\hline Return (\% per month) & & 2.41 & 2.6 & 2.14 & 2.48 \\
\hline $\begin{array}{l}\text { Standard Deviation } \\
(\%)\end{array}$ & & 2.75 & 2.9 & 2.88 & 3.31 \\
\hline $\mathrm{N}$ & & 20 & 19 & 20 & 19 \\
\hline$\beta$ IBrX & & 0.73 & 0.77 & 0.87 & 1.02 \\
\hline
\end{tabular}

\begin{tabular}{|c|c|c|c|c|c|}
\hline \multicolumn{6}{|c|}{ Panel C - Portfolios ordered by the $\mathrm{B} / \mathrm{M}$ ratio } \\
\hline & Portfolio 0 & Portfolio 1 & Portfolio 2 & Portfolio 3 & Portfolio 4 \\
\hline $\mathrm{P} / \mathrm{E}$ & & 17.17 & 12.53 & 13.63 & 16.04 \\
\hline MV & & 20.08 & 21.60 & 13.69 & 6.35 \\
\hline $\mathrm{B} / \mathrm{M}$ & & 0.4 & 1.11 & 1.8 & 4.01 \\
\hline Return (\% per month) & & 2.44 & 2.47 & 2.85 & 1.96 \\
\hline Standard Deviation $\%$ & & 2.88 & 2.74 & 3.07 & 2.93 \\
\hline $\mathrm{N}$ & & 20 & 19 & 20 & 19 \\
\hline$\beta$ IBrX & & 0.83 & 0.88 & 0.86 & 0.84 \\
\hline
\end{tabular}

Source: Data from the study.

Table 3 contains a correlation matrix between all the variables utilized, ordered individually by the variables $\mathrm{P} / \mathrm{E}, \mathrm{MV}$ and $\mathrm{B} / \mathrm{M}$. The intention is to verify if there is any degree of correlation between the variables before application of the econometric tests.

Table 3 - Correlation matrix of the fundamental variables

\begin{tabular}{lcccc}
\hline \multicolumn{5}{c}{ CORRELATION MATRIX } \\
\hline & $\mathrm{IBrX}$ & $\mathrm{P} / \mathrm{E}$ & $\mathrm{MV}$ & $\mathrm{B} / \mathrm{M}$ \\
$\mathrm{IBrX}$ & $\mathbf{1}$ & -0.019658 & 0.328477 & 0.252884 \\
$\mathrm{P} / \mathrm{E}$ & -0.019658 & $\mathbf{1}$ & 0.081971 & -0.126322 \\
$\mathrm{MV}$ & 0.328477 & 0.081971 & $\mathbf{1}$ & -0.499105 \\
$\mathrm{~B} / \mathrm{M}$ & 0.252884 & -0.126322 & -0.499105 & $\mathbf{1}$ \\
\hline
\end{tabular}

Source: Data from the study.

The results indicate some correlation between the fundamental variables. The market value and $\mathrm{B} / \mathrm{M}$ variables have a high correlation of 0.49 , but with inverse signs, indicating 
these variables can influence each other's results when compared together. This effect was expected, since all the variables contain the price of the assets, influencing their composition.

Table 4 contains an analysis of applying the SUR method in the portfolios formed by the four variables analyzed in this study: beta, P/E, MV and B/M. All eight portfolios were ordered respecting the criteria presented in the descriptive analysis, that is, first they were ordered by the P/E index, then by MV and finally by B/M.

Table 4 - Estimated relation between the returns and the unsmoothed fundamental variables using the SUR technique

\begin{tabular}{|c|c|c|c|c|c|c|}
\hline Model & Intercept & Beta IBrX & $\mathbf{P} / \mathbf{E}$ & LMV & B/M & Adjusted \\
\hline n & $\begin{array}{l}0.018748 \\
0.0861^{*}\end{array}$ & $\begin{array}{l}-0.012042 \\
0.2679 \\
\end{array}$ & & & & U.U $\angle 01 J 4$ \\
\hline 1 & $\begin{array}{l}0.009702 \\
0.4081\end{array}$ & $\begin{array}{l}-0.010955 \\
0.3114\end{array}$ & $\begin{array}{l}0.000688 \\
0.0506^{*}\end{array}$ & & & U.V1 $\angle I 10$ \\
\hline ○ & $\begin{array}{l}-0.138653 \\
0.0916^{*}\end{array}$ & $\begin{array}{l}-0.011560 \\
0.2868\end{array}$ & & $\begin{array}{l}0.010183 \\
0.0541 *\end{array}$ & & U.U1 $\angle$ UOS \\
\hline ○ & $\begin{array}{l}0.026115 \\
0.0200^{*} *\end{array}$ & $\begin{array}{l}-0.008363 \\
0.4370 \\
\end{array}$ & & & $\begin{array}{l}-0.010499 \\
0.0008 * * *\end{array}$ & דנגנטגטג \\
\hline 1 & $\begin{array}{l}-0.124414 \\
0.1305\end{array}$ & $\begin{array}{l}-0.010929 \\
0.3119\end{array}$ & $\begin{array}{l}0.000618 \\
0.0806^{*}\end{array}$ & $\begin{array}{l}0.008752 \\
0.0992 *\end{array}$ & & U.U1ग40/ \\
\hline$\tau$ & $\begin{array}{l}-0.022699 \\
0.8041\end{array}$ & $\begin{array}{l}0.008499 \\
0.4306\end{array}$ & & $\begin{array}{l}0.003145 \\
0.5893\end{array}$ & $\begin{array}{c}-0.010060 \\
0.0032 * * *\end{array}$ & 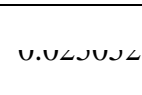 \\
\hline r & $\begin{array}{l}0.018959 \\
0.1214\end{array}$ & $\begin{array}{l}-0.008028 \\
0.4550\end{array}$ & $\begin{array}{l}0.000495 \\
0.1639\end{array}$ & & $\begin{array}{c}-0.009473 \\
0.0029 * * *\end{array}$ & $\mathrm{U} . \mathrm{v} \angle \mathrm{U}<\mathrm{O} \angle$ \\
\hline 7 & $\begin{array}{l}-0.018926 \\
0.8364\end{array}$ & $\begin{array}{l}-0.008002 \\
0.4573\end{array}$ & $\begin{array}{l}0.000493 \\
0.1662\end{array}$ & $\begin{array}{l}0.002447 \\
0.6751\end{array}$ & $\begin{array}{c}-0.009305 \\
0.0068 * * *\end{array}$ & $\mathrm{v} \cdot \mathrm{v} \angle \mathrm{U} \triangle \supset \triangle$ \\
\hline
\end{tabular}

Note:

P-values: * $\quad$ significant at $10 \%$

** significant at $5 \%$

*** significant at $1 \%$

Source: Data from the study.

Table 4 includes the analysis of the eight models, with the first four containing an individual analysis of each variable considered. The next three include the variables analyzed in pairs and the last model includes a joint analysis of all the variables together. In this step, the fundamental variables were not smoothed for variations in level over time.

Table 4 presents results different from those observed by the descriptive analysis presented in Table 2 .

The variables when analyzed individually have significant coefficients, with the variables $\mathrm{P} / \mathrm{E}$ and $\mathrm{MV}$ being significant at the $10 \%$ level. The variable that stands out most is $\mathrm{B} / \mathrm{M}$, significant at $1 \%$ in all seven models. This effect of the explanatory power of this variable is called the value effect. The results corroborate the findings of Neves (1996), 
Braga, Costa Jr. \& Mescolin (1997), Lima Jr. (2003) and Malaga \& Securato (2004) for the Brazilian market.

As found by Fama \& French (1992), the variable beta was not significant in any of the models evaluated. This low explanatory power can be partly explained by some limitations due to the process of forming the IBrX index, which includes in its theoretical portfolio firms with a small history of price quotations, hindering the use of betas over periods longer than 24 months. Nevertheless, the results indicate that the other variables explain the excess returns better.

With respect to the adjusted $\mathrm{R}^{2}$, which shows low explanatory power of the models, there is a small increase when the $\mathrm{B} / \mathrm{M}$ variable is introduced in the models.

With the objective of correcting possible model specification error, we divided each fundamental variable by the average cross section of the month of the four month period before the change in the portfolios. The results with the smoothed variables are presented in Table 5.

Table 5 - Estimated relation between returns and the smoothed fundamental variables using the SUR technique

\begin{tabular}{|c|c|c|c|c|c|c|}
\hline Model & Intercept & Beta IBrX & $\mathbf{P} / \mathbf{E}$ & LMV & $\mathbf{B} / \mathbf{M}$ & Adjusted \\
\hline n & $\begin{array}{l}-0.019708 \\
0.07976^{*}\end{array}$ & $\begin{array}{l}-0.009159 \\
0.4142\end{array}$ & & & & U.U $\angle 01 \supset 4$ \\
\hline 1 & $\begin{array}{l}-0.005030 \\
0.6951\end{array}$ & $\begin{array}{l}-0.002886 \\
0.7984 \\
\end{array}$ & $\begin{array}{l}0.014809 \\
0.0004 * * *\end{array}$ & & & U.UJUJAY \\
\hline ○ & $\begin{array}{l}-0.051993 \\
0.1204\end{array}$ & $\begin{array}{l}-0.009173 \\
0.4119\end{array}$ & & $\begin{array}{l}0.078415 \\
0.0229 * *\end{array}$ & & U.viYוo/ \\
\hline ○ & $\begin{array}{l}0.051955 \\
0.0001 * * * \\
\end{array}$ & $\begin{array}{l}-0.007723 \\
0.4940\end{array}$ & & & $\begin{array}{l}-0.036542 \\
0.0000 * * *\end{array}$ & U.v/1004 \\
\hline 1 & $\begin{array}{l}-0.073611 \\
0.0262 * *\end{array}$ & $\begin{array}{l}-0.003041 \\
0.7870 \\
\end{array}$ & $\begin{array}{l}0.014531 \\
0.0004 * * *\end{array}$ & $\begin{array}{l}0.075533 \\
0.0236^{* *}\end{array}$ & & u.vyYiu \\
\hline$\tau$ & $\begin{array}{l}-0.001228 \\
0.9711\end{array}$ & $\begin{array}{l}-0.007980 \\
0.4793 \\
\end{array}$ & & $\begin{array}{l}0.057099 \\
0.0900^{*}\end{array}$ & $\begin{array}{c}-0.035253 \\
0.0000 * * * \\
\end{array}$ & v.viveru \\
\hline r & $\begin{array}{c}0.034603 \\
0.0264 * * \\
\end{array}$ & $\begin{array}{l}-0.004417 \\
0.6978 \\
\end{array}$ & $\begin{array}{l}0.008638 \\
0.0506^{*} \\
\end{array}$ & & $\begin{array}{l}-0.033026 \\
0.0000 * * *\end{array}$ & ט.vivi \\
\hline 7 & $\begin{array}{l}-0.023233 \\
0.5044\end{array}$ & $\begin{array}{l}-0.004510 \\
0.6911\end{array}$ & $\begin{array}{l}0.008903 \\
0.0433 * *\end{array}$ & $\begin{array}{l}0.061495 \\
0.0632 *\end{array}$ & $\begin{array}{l}-0.031577 \\
0.0000 * * *\end{array}$ & נו \\
\hline
\end{tabular}

Note.

P-values: * significant at $10 \%$

** significant at $5 \%$

$* * *$ significant at $1 \%$

Source: Data from the study.

This smoothing produced a change in the estimated coefficients in relation to the results presented in Table 4, mainly regarding the explanatory power of the variables analyzed. The fundamental variable stood out continued to be $\mathrm{B} / \mathrm{M}$, a result that is consistent 
with the studies mentioned earlier. This variable was the only one that was statistically significant in all the models.

In comparison to the results found by Neves (1996), the P/E variable showed strong significance $(1 \%)$ when analyzed individually in model 1, and significance of $5 \%$ when included in model 7 with all the variables.

On the other hand, while the market value variable also is highly significant when analyzed alone, it loses significance when the $\mathrm{B} / \mathrm{M}$ variable is introduced in the model. The results obtained for this variable individually corroborate the size effect, in line with the results of Fama \& French (1992) and Neto (2008).

Therefore, as can be seen in the results presented in Table 4, beta continues not having any explanatory power. In relation to the adjusted $\mathrm{R}^{2}$, the explanatory power of the models improves when the variables are smoothed by their means. In this context, of all the models, model 7, which includes all the variables, has the highest adjusted $\mathrm{R}^{2}$, with all the variables being statistically significant.

As described in the methodology section, in each succeeding step all the calculations carried out with the SUR technique were repeated using TSCS regression. Table 6 shows the results, with the unsmoothed variables.

Table 6 - Estimated relation between the returns and the unsmoothed fundamental variables using the TSCS regression technique

\begin{tabular}{|c|c|c|c|c|c|c|}
\hline Model & Intercept & Beta IBrX & $\mathbf{P} / \mathbf{E}$ & LMV & B/M & Adjusted \\
\hline$n$ & $\begin{array}{l}0.018973 \\
0.0826^{*}\end{array}$ & $\begin{array}{l}-0.012302 \\
0.2578\end{array}$ & & & & U.U $\angle \angle U Y S$ \\
\hline 1 & $\begin{array}{l}0.009853 \\
0.4016\end{array}$ & $\begin{array}{l}-0.011118 \\
0.3045\end{array}$ & $\begin{array}{l}0.000687 \\
0.0509 *\end{array}$ & & & U.U1 $\angle I / O$ \\
\hline ○ & $\begin{array}{l}-0.138102 \\
0.0930 * \\
\end{array}$ & $\begin{array}{l}-0.011804 \\
0.2768 \\
\end{array}$ & & $\begin{array}{l}0.010161 \\
0.0547^{*}\end{array}$ & & U.U1 $\angle 1 \angle J$ \\
\hline ○ & $\begin{array}{l}0.026284 \\
0.0192 * *\end{array}$ & $\begin{array}{l}-0.008590 \\
0.4249 \\
\end{array}$ & & & $\begin{array}{c}-0.010469 \\
0.0009 * * *\end{array}$ & 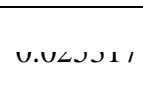 \\
\hline 1 & $\begin{array}{l}-0.123889 \\
0.1322 \\
\end{array}$ & $\begin{array}{l}-0.011091 \\
0.3050\end{array}$ & $\begin{array}{l}0.000618 \\
0.0810^{*}\end{array}$ & $\begin{array}{l}0.008727 \\
0.1002\end{array}$ & & ט.טונכנט \\
\hline$\tau$ & $\begin{array}{l}-0.022255 \\
0.8079 \\
\end{array}$ & $\begin{array}{l}-0.008723 \\
0.4188 \\
\end{array}$ & & $\begin{array}{l}0.003128 \\
0.5913\end{array}$ & $\begin{array}{c}-0.010040 \\
0.0032 * * * \\
\end{array}$ & v.v $\triangle J \cup \angle J$ \\
\hline r & $\begin{array}{l}0.019070 \\
0.1197\end{array}$ & $\begin{array}{l}-0.008190 \\
0.4462\end{array}$ & $\begin{array}{l}0.000496 \\
0.1636\end{array}$ & & $\begin{array}{c}-0.009446 \\
0.0029 * * *\end{array}$ & $v \cdot v<v<J 1$ \\
\hline$\neg$ & $\begin{array}{l}-0.018403 \\
0.8409\end{array}$ & $\begin{array}{l}-0.008158 \\
0.4489\end{array}$ & $\begin{array}{l}0.000494 \\
0.1658\end{array}$ & $\begin{array}{l}0.002420 \\
0.6784\end{array}$ & $\begin{array}{c}-0.009290 \\
0.0069 * * *\end{array}$ & $v \cdot v<v<1 J$ \\
\hline
\end{tabular}

Note.

P-values: * significant at $10 \%$

** significant at $5 \%$

$* * *$ significant at $1 \%$

Source: Data from the study. 
This test thus included, as did the others, all the fundamental variables, but not yet adjusted. The results provided by the TSCS method are very similar to those obtained by the SUR. The variables continue having some explanatory power when analyzed individually, with $\mathrm{P} / \mathrm{E}$ and market value being significant at $10 \%$. Furthermore, even though using a different technique to calculate the coefficients between the variables, the most representative one continues to be the $\mathrm{B} / \mathrm{M}$ ratio. Beta behaves the same as when using the other techniques, without any explanatory power.

Once again, the adjusted $\mathrm{R}^{2}$ shows low explanatory power of the models, but slightly higher when the $\mathrm{B} / \mathrm{M}$ variable is introduced, as found before in Table 4.

As previously, we again estimated the same models with the variables smoothed, to detect if the TSCS method is capable of providing better estimates, because it takes into account the variables already adjusted to level by considering a possible variation in their cross-sectional distribution. The results with the smoothed variables are shown in Table 7.

Table 7- Estimated relation between the returns and smoothed fundamental variables using the TSCS regression technique

\begin{tabular}{|c|c|c|c|c|c|c|}
\hline Model & Intercept & Beta IBrX & $\mathbf{P} / \mathbf{E}$ & LMV & B/M & Adjusted \\
\hline $\mathrm{n}$ & $\begin{array}{l}0.022524 \\
0.0621 *\end{array}$ & $\begin{array}{l}-0.001577 \\
0.8996\end{array}$ & & & & U.voU $\angle I J$ \\
\hline 1 & $\begin{array}{l}-0.006963 \\
0.6370\end{array}$ & $\begin{array}{l}0.008852 \\
0.4960\end{array}$ & $\begin{array}{l}0.019150 \\
0.0005^{* * *}\end{array}$ & & & U.U/U $</ 4$ \\
\hline ○ & $\begin{array}{c}-0.371811 \\
0.0033 * * * \\
\end{array}$ & $\begin{array}{l}-0.000854 \\
0.9463\end{array}$ & & $\begin{array}{l}0.391246 \\
0.0016^{* * *}\end{array}$ & & ט.טDo/y \\
\hline ○ & $\begin{array}{l}0.057490 \\
0.0000 * * *\end{array}$ & $\begin{array}{l}0.000698 \\
0.9554\end{array}$ & & & $\begin{array}{c}-0.040286 \\
0.0000^{* * *}\end{array}$ & ו וניניט \\
\hline 1 & $\begin{array}{c}-0.413374 \\
0.0012 * * *\end{array}$ & $\begin{array}{l}0.009284 \\
0.4741\end{array}$ & $\begin{array}{l}0.018285 \\
0.0008 * * *\end{array}$ & $\begin{array}{l}0.404418 \\
0.0011 * * *\end{array}$ & & U. $000 \angle 4 /$ \\
\hline$\tau$ & $\begin{array}{l}-0.237150 \\
0.0606^{*}\end{array}$ & $\begin{array}{l}0.000265 \\
0.9832\end{array}$ & & $\begin{array}{l}0.289345 \\
0.0186^{* *}\end{array}$ & $\begin{array}{c}-0.036109 \\
0.0000^{* * *}\end{array}$ & נוננטוגט \\
\hline$r$ & $\begin{array}{c}0.041144 \\
0.0233 * *\end{array}$ & $\begin{array}{l}0.004955 \\
0.7016\end{array}$ & $\begin{array}{l}0.008652 \\
0.1430\end{array}$ & & $\begin{array}{c}-0.036564 \\
0.0000^{* * *}\end{array}$ & ט.טフフルU \\
\hline$\neg$ & $\begin{array}{l}-0.270655 \\
0.0361 * *\end{array}$ & $\begin{array}{l}0.005092 \\
0.6943\end{array}$ & $\begin{array}{l}0.009004 \\
0.1243\end{array}$ & $\begin{array}{l}0.304696 \\
0.0139 * *\end{array}$ & $\begin{array}{c}-0.031457 \\
0.0001 * * *\end{array}$ & v.1U+000 \\
\hline
\end{tabular}

Note.

P-values: * significant at $10 \%$

** significant at $5 \%$

*** significant at $1 \%$

Source: Data from the study.

As can be seen, the introduction of smoothing increases the explanatory power of the variables; all of them are significant at $1 \%$ in models 1 to 3 .

Another noteworthy point is the importance of market value in the analysis, which consistently shares approximately the same explanatory power as the $\mathrm{B} / \mathrm{M}$ ratio in the seven 
models, and is significant at 5\% in model 7 , which includes all the variables. The B/M variable continues having strong explanatory power, as in the other tests, remaining significant at $1 \%$. In contrast, while the $\mathrm{P} / \mathrm{E}$ variable has strong significance when analyzed alone, it loses explanatory power when the $\mathrm{B} / \mathrm{M}$ variable is introduced in the equation. And beta continues to have no explanatory power.

In relation to adjusted $\mathrm{R}^{2}$, the models' explanatory power improves when the variables are smoothed. Once again, model 7 has the highest adjusted $\mathrm{R}^{2}$.

For the purpose of checking whether the sensitivity of the results obtained before would change when altering the portfolio formation process, we ran the same regressions again but this time with two different procedures to order the fundamental variables. First we formed the portfolios by the MV variable, followed by the P/E ratio and then the $\mathrm{B} / \mathrm{M}$ index, then by the starting with the $\mathrm{B} / \mathrm{M}$ variable and lastly starting with the MV variable. As done before, all the procedures involved forming eight portfolios.

The results of these orderings are not presented in detail here, but the following conclusions can be reached: ${ }^{\mathrm{i}}$

For the portfolios ordered first by the MV variable, there were different significance levels between this variable and P/E, depending on the test applied. For the portfolios formed according to the $\mathrm{B} / \mathrm{M}$ variable, there were significant changes regarding the behavior of $\mathrm{P} / \mathrm{E}$ and MV, which lost significance in all the models. Only the $\mathrm{B} / \mathrm{M}$ variable showed stability in all the tests applied, and also was highly significant (1\%) in the great majority of the models analyzed. As before, beta was not statistically significant in any of the tests.

\section{CONCLUSIONS}

The main objective of this study was to investigate the influence of beta, the priceearnings ratio, market value and the book-to-market ratio on the returns of Brazilian stocks making up the IBrX during the period from May 2002 to December 2007.

Based on the econometric calculations, we found that all these variables except beta have significant influence on the cross-sectional variations of the average returns, which agrees with the findings of Fama \& French (1992) in the United States. The low significance of beta can be associated with the process of forming the IBrX, whose theoretical portfolio contains firms with short stock return series, limiting the use of betas to periods under 24 months. 
The behavior of the variables changed as the methods of analysis changed. For the portfolios ordered first by the $\mathrm{P} / \mathrm{E}$ variable, there were changing levels of significance between this variable and market value, depending on the test applied. The same thing happened when the portfolios were ordered by MV, i.e., the P/E and MV variables alternated in being most significant. Finally, when the ordering started with the B/M variable, both the $\mathrm{P} / \mathrm{E}$ and $\mathrm{MV}$ variables lost statistical significance.

The BM variable was the only one that presented stable results in all the tests applied in this study, besides being highly significant, corroborating similar results found by other authors for the Brazilian market, such as Neves (1996), Braga, Costa Jr. \& Mescolin (1997), Rodrigues (2000) and Lima (2003).

The stock price was directly related to the behavior of the P/E and MV variables, and indirectly to the $\mathrm{B} / \mathrm{M}$ variable. In this respect, there was a strong influence of the price on the returns and the results obtained.

Besides the above, this study indicates that the anomalies commonly found in articles questioning the efficient market hypothesis persist in the Brazilian capital market. This shows there are still questions about the misspecification of the CAPM, although that model should not be disregarded altogether, since other studies in Brazil have confirmed the significance of market beta (Medeiros, 2009; Mussa, Santos \& Famá, 2007).

Future studies could observe how these fundamental variables behave during moments of crisis. An option would be to analyze the period between May 2008 and March 2009, when the peak effects of the financial crisis were felt in Brazil. Since this is a very short period, an alternative would be to use a conditional CAPM with daily or weekly data. There are few studies that have used models with low-frequency data to investigate anomalies. A good reference is the article by Lewellen \& Nagel (2003), who used a conditional CAPM, adapting it also to calculate the betas in the three-factor model, and did not find any significant evidence of anomalies.

\section{REFERENCES}

BANZ, R.W. The relationship between return and market value of common stocks. Journal of Financial Economics, v. .9, p.3-18, March 1981.

BASU, S. Investment performance of common stocks in relation to their price/earnings ratios: A test of the efficient market hypothesis. Journal of Finance, v. 32, p. 663-682, 1977. 
BMFBOVESPA (2010). Metodologia Completa do IBrX-50. Available at http://bmfbovespa.com.br/indices. Retrieved on May 25, 2010.

BRAGA, C., COSTA JR., N.C.A. da; MESCOLIN A. Risco e retorno das value e growth stocks no mercado de capitais brasileiro. In: Encontro Anual da Associação Nacional dos Programas de Pós-graduação em Administração, 21, 1997, Rio de Janeiro. Anais... Rio de Janeiro: ANPAD, 1997.

BRITO, N. R. O. Gestão de Investimentos. 1st ed., São Paulo: Atlas, 1989. Chap. 5.

BROOKS, C. Introductory Econometrics for Finance. 2nd edition. Cambridge: Cambridge University Press, 2008.

CARHART, M. M. On Persistence in Mutual Fund Performance. Journal of Finance, v. 52, n. 1 , pp. $57-81,1997$

CHAN, L. K. C.; HAMAO, Y.; LAKONISHOK, J. Fundamentals and stock returns in Japan. The Journal of Finance, v. 46, pp. 1739-1764, Dec.1991.

FAMA, E. F.; FRENCH, K. R. The cross-section of expected stock returns. The Journal of Finance, v.47, pp. 427-465, 1992.

. Common risk factors in the returns on stocks and bonds.

Journal of Financial Economics, v. 33, pp. 3-56, 1993.

HAZZAN, S. Desempenho de Ações da Bolsa de Valores de São Paulo e sua relação com o índice preço-lucro. Doctoral Thesis, São Paulo, EAESP/FGV, 263p.,1991.

HSIAO, C. Analysis of Panel Data. Cambridge: Cambridge University Press, 1986.

JEGADEESH, N.; TITMAN, S. Returns to Buying Winners and Selling Losers: Implications for Stock Market Efficiency. Journal of Finance, v. 48, n. 1, pp. 65-91, 1993.

LEWELlEN, J. W.; NAGEL, S. The Conditional CAPM Does Not Explain Asset-pricing Anomalies. SSRN eLibrary, 2003.

LIMA JUNIOR, H. S. Um estudo das anomalias no apreçamento de ações no mercado brasileiro utilizando o modelo de quatro fatores, 2003. 109p. Master's Dissertation, PUCRio, Rio de Janeiro.

MÁLAGA, F. K.; SECURATO, J. R. Aplicação do modelo de três fatores de Fama \& French no mercado acionário brasileiro - um estudo empírico do período de 1995-2003. In: Encontro 
Anual da Associação Nacional do Programas de Pós-Graduação em Administração, 28, 2004. Anais... Curitiba: ANPAD, 2004.

MEDEIROS, K. S. G. Estudo dos Retornos das Ações das Empresas Brasileiras de Energia Elétrica: Uma análise comparativa utilizando os modelos CAPM, Fama \& French e quatro fatores de Carhart. Master's Dissertation, UFPE, Recife, 2009.

MARKOWITZ, H. Portfolio Selection. The Journal of Finance, vol. VII - no.1, pp. 77-91, 1952.

MUSSA, A. SANTOS, J. O., FAMA, R. A Adição do Fator de Risco Momento ao Modelo de Precificação de Ativos dos Três Fatores de Fama \& French, Aplicado ao Mercado Acionário Brasileiro. In: Congresso USP de Controladoria e Contabilidade, 7, 2007. Anais... São Paulo, 2007.

NETO, A. Revisitando o Modelo de Apreçamento de Ativos a la Cahart para o Mercado Acionário Brasileiro, Master's Dissertation, UFC, Fortaleza, 2008.

NEVES, M. B. E. Utilização do Beta, índice P/E, Valor de Mercado e Valor contábil na relação risco-retorno no mercado acionário brasileiro. Master's Dissertation, UFRJ, Rio de Janeiro, 1996.

RODRIGUES, M.R.A. O efeito valor, o efeito tamanho e o modelo multifatorial: evidências do caso brasileiro, In: Encontro Anual da Associação Nacional dos Programas de Pósgraduação em Administração, 24, 2000, Florianópolis. Anais...Florianópolis: ANPAD, 2000.

${ }^{\mathrm{i}}$ The results are available from the authors by e-mail on request. 